\title{
Is the partner who decides to divorce more attractive? A comparison between initiators and non-initiators
}

\author{
Charvoz, L ; Bodenmann, Guy ; Bertoni, A ; Iafrate, R ; Giuliani, C
}

\begin{abstract}
Germany, Italy and Switzerland provided retrospective reports on the perceived similarity and differences between themselves and their former partner and on their own and their partner's attractiveness. Initiators and noninitiators were compared with regard to these different variables. Results demonstrated that most divorcees perceived themselves to be quite similar to their former partner. Initiating women were more numerous than nonintiating to perceive themselves to be different from their former partner in personality, norms and needs and to evaluate their former partner to be less attractive. Initiating men were more numerous than nonitiating to perceive differences with regard to the personality between themselves and their partner.
\end{abstract}

DOI: https://doi.org/10.1080/10502550802365516

Posted at the Zurich Open Repository and Archive, University of Zurich

ZORA URL: https://doi.org/10.5167/uzh-24371

Journal Article

Accepted Version

Originally published at:

Charvoz, L; Bodenmann, Guy; Bertoni, A; Iafrate, R; Giuliani, C (2009). Is the partner who decides to divorce more attractive? A comparison between initiators and non-initiators. Journal of Divorce and Remarriage, 50(1):22-37.

DOI: https://doi.org/10.1080/10502550802365516 
Is the partner who decides to divorce more attractive? A comparison between initiators and non-initiators

RUNNING TITLE: Initiator status, attractiveness and divorce

\author{
Linda Charvoz Guy Bodenmann \\ University of Fribourg \\ Switzerland
}

Anna Bertoni Raffaella Iafrate Christina Giuliani

Centro Studi e Ricerche sulla Famiglia

Università Cattolica del Sacro Cuore di Milano

Italy 
Abstract

580 divorced individuals from Germany, Italy and Switzerland provided retrospective reports on the perceived similarity and differences between themselves and their former partner and on their own and their partner's attractiveness. Initiators and noninitiators were compared with regard to these different variables. Results demonstrated that most divorcees perceived themselves to be quite similar to their former partner. Initiating women were more numerous than nonintiating to perceive themselves to be different from their former partner in personality, norms and needs and to evaluate their former partner to be less attractive.

Initiating men were more numerous than nonitiating to perceive differences with regard to the personality between themselves and their partner.

Keywords: divorce, attractiveness, alternatives, initiator status 
Nowadays a large proportion of marriages are projected to end in divorce (Bramlett \& Mosher, 2002; Eurostat, 2001; Sayers, Kohn, \& Heavey, 1998). To understand this phenomenon, numerous studies already focused on the evolution of marital decline and marital dissolution (e.g. Amato \& Previti, 2003; Zimmer, 2001). The purpose of the present study was to compare the spouse who initiated divorce and his/her mate with respect to the own and partner's attractiveness (income, profession, sex appeal, social integration, moral values, ideas, etc.). Several theories and former studies yielded the background of this study, thus theories explaining the mate selection (attractiveness of the romantic partner, similarity vs difference between the partners), social exchange theory (Levinger, 1976; Lewis \& Spanier, 1979; Rusbult, 1983), equity theory (Walster, Walster \& Berscheid, 1978), and studies that investigated characteristics of spouses who initiated divorce compared to partner who did not.

Within mate selection approaches, most studies predicted that men preferred physically/sexually attractive women (e.g. Berry \& Miller, 2001; Buss, 1989; Howard, Blumstein \& Schwartz, 1987) and that, in opposite, women would prefer men who had an attractive socio-economic status (Berscheid \& Walster, 1974; Klein, 1991; Townsend \& Wasserman, 1997). These differences in partner preferences had been explained in terms of social role theory (e.g. Archer, 1996; Eagly, 1987) and within an evolutionary perspective (e.g. Buss \& Barnes, 1986; Kenrick \& Trost, 1993). However many studies on the attractiveness of romantic partners reported a strong "assortative mating". Indeed individuals preferred partners who were physically and psychologically similar with regard to attractiveness (Buss \& Barnes, 1986; Feingold, 1988; Lykken \& Tellegen, 1993). In comparable lines, several studies confirmed that individuals were initially assorted on similarity, rather than that both partners became similar over time (e.g., Buss, 1984). In contrast, spouses' similarity on temperament (Stevenson \& Fielding, 1985), attitudes and 
values (Feng \& Baker, 1994; Nagoshi \& Johnson, 1994), intelligence (Gilger, 1991) tended to be lower than spouses'similarity on physical and psychological level. Contradictory results were reported examining correlations between spouses' similarity and marital quality and satisfaction: several researchers found positive correlations between partners' similarity and marital quality and/or satisfaction (e.g. Kurdek, 1993; Richard, Wakefield, \& Lewak, 1990; Russel \& Wells, 1991, 1994), but other authors couldn't replicate such correlations (Lewak, Wakefield, \& Briggst, 1985).

According to social exchange theory developed by Thibaut and Kelley (1959), Levinger (1976) suggested that marital cohesion depends on (a) the attractiveness of the close relationship, (b) the attractiveness of alternatives and (c) the barriers to divorce. Partners who perceived more rewards (e.g., material, symbolic, emotional) than costs (e.g., loss of freedom, responsibilities, compromises) in their marriage are expected to remain committed to the marriage and to experience relatively high levels of relationship satisfaction (Bradbury, Fincham \& Beach, 2000; Glenn, 1990; 1991; Johnson, Amoloza \& Booth, 1992; Johnson, Caughlin \& Huston, 1999; Knoester \& Booth, 2000) and low rates of divorce (Booth, Johnson, White \& Edwards, 1986; Heaton \& Albrecht, 1991; White and Booth, 1991). In contrast, spouses who are not attracted to their marriage (as a result of perceiving more costs than benefits in their relationship) are likely to experience distress and will remain married only in the presence of high barriers to divorce (e.g., concerns about children, moral or religious constrains) (Levinger, 1976) and poor alternatives (e.g., lack of a desirable new partner) (e.g., South \& Lloyd, 1995; Trent \& South, 2003; Udry, 1981; White \& Booth, 1991).

Several studies based on equity theory (Walster et al., 1978) reported that both partners would be most satisfied with their relationship when it is considered as equitable, meaning that each one's outcomes from the relationship are similar to each one's 
contributions (Buunk \& VanYperen, 1991; Cate, Lloyd, Henton \& Larson, 1982; Deutsch, 1975; Hatfield, Utne, \& Traupman, 1979). When a partner perceives him/herself participating in an inequitable way, he/she should feel distressed in marriage and should be prone to develop negative emotions (i.e., frustration, feelings of unfairness, depression, guilty, shame, etc.) (e.g. Sprecher, 1986). Several scholars reported that the under benefited spouse (Prins, Buunk, \& VanYperen, 1993; Walster, Traupman \& Walster; 1978), particularly women, were most "likely to engage in an extramarital relationship, often the first step to ending a marriage" (Buunk \& Mutsaers, 1999, p 125).

The fourth line of studies deals with the question of who initiates divorce. According to Pettit and Bloom (1984), making the decision to divorce is a «complex dyadic process». The different steps in this process may vary from couple to couple (e.g., mutual decision to separate; a spouse decides to divorce surprising the other partner (Goodman, 1993); a spouse may provoke the other to initiate divorce (Meyers, 1995)). Different studies affirm that in about $2 / 3$ of cases, the decision to divorce is made by the wife (Braver, Whitley, \& $\mathrm{Ng}, 1993$; Chang, 2000; Rokach, Cohen \& Dreman, 2004). Several theoretical models of divorce submitted that the initiative to divorce is influenced by marital unhappiness, desirable alternatives and attractions, and personality factors (Becker, 1981; Levinger, 1979; Pettit \& Bloom, 1984). However, a number of recent studies (Hopper, 1993; Sweeney, 2002) found only few differences between initiating and non-initiating partners with regard to their personality and the degree of marital distress. More differences have been found on marital alternatives (Black, Eastwood, Sprenkle \& Smith, 1991; Udry, 1981; White \& Booth, 1991). Rokach et al. (2004) reported that the initiator of divorce is described as dominant in the couple. These authors concluded that the dominant spouse (the one with the greatest power) more frequently initiates divorce because he/she is the more active partner, the more attractive, and the one with the best alternatives. Vaughan (1986) explained the difference 
between initiating and non-initiating partners by the fact that the initiator has more time to detect possible alternatives to the current relationship.

Our study aims to compare the partner who initiated divorce and his/her mate with respect to the own and the partner's attractiveness (i.e., income, profession, sex appeal, social integration, moral values, ideas, etc.). We expected that the spouse who decides to dissolve marriage, evaluates him/herself to be more attractive than his/her partner. Moreover we expected that women who made the decision to divorce considered themselves to be physically more attractive than non-initiating women and that male initiators evaluated themselves to be more attractive than non-initiators with respect to socioeconomic status.

\section{Method}

\section{$\underline{\text { Participants }}$}

703 divorced subjects between 20 and 60 participated in this research. Participants were recruited with community-wide advertisements in newspapers in 2002 in Germany, Italy and Switzerland. In this study participants who indicated to have taken the decision to separate were considered as the "initiators of divorce" and subjects who indicated that their partner had decided to divorce as the "non-initiators". We decided not to take into account the 123 participants (55 women and 68 men) who admitted that the decision to divorce was a mutual decision. We finally based our analyses on 580 subjects (366 women and 214 men), as shown in table 1.

Initiators and non-initiators were compared on sociodemographic variables to identify any differences between them. Decision to divorce was mostly taken by the wife, $\chi^{2}(1)=$ $52.38 ; \mathrm{p}<.000$, according to the affirmations of women $(72.4 \%$ of them estimated to have 
initiated divorce) and to the affirmations of the men (57.9\% of them reported that the decision was taken by their partner).

There were no differences between initiators and noninitiators, among women and men, with regard to the age at the time of data collection [women: $(\underline{\mathrm{t}}(359)=-.34$; $\underline{\mathrm{ns}})$, men: $(\underline{\mathrm{t}}(208)=-1.75 ; \underline{\mathrm{ns}})]$, to the age at the time of marriage [women: $(\underline{\mathrm{t}}(360)=-.59 ; \underline{\mathrm{ns}})$, men: $(\underline{t}(212)=-1.90 ; \underline{\mathrm{ns}})]$, to the duration of the engagement prior to marriage [women: $(\mathrm{t}(360)=-$ 1.96; $\underline{\mathrm{ns}})$, men: $(\underline{\mathrm{t}}(208)=-.93 ; \underline{\mathrm{ns}})]$, to the duration of cohabitation prior to the marriage [women: $(\underline{\mathrm{t}}(272)=.42 ; \underline{\mathrm{ns}})$, men: $(\underline{\mathrm{t}}(164)=-.32 ; \underline{\mathrm{ns}})]$, to the duration of the marital relationship [women: $(\underline{\mathrm{t}}(355)=-1.48 ; \underline{\mathrm{ns}})$, men: $(\underline{\mathrm{t}}(208)=-.45 ; \underline{\mathrm{ns}})]$, and finally to the duration since the separation [women: $(\underline{\mathrm{t}}(360)=1.72 ; \underline{\mathrm{ns}})$, men: $(\underline{\mathrm{t}}(207)=-.46 ; \underline{\mathrm{ns}})]$.

Moreover, there were no differences between the initiators and noninitiators, men and women, with regard to nationality [women: $\chi^{2}(2)=1.22 ; \underline{\mathrm{ns}}$, men: $\chi^{2}(2)=.44 ; \underline{\mathrm{ns}}$ ], religion [women: $\chi^{2}(2)=1.51$; $\underline{\mathrm{ns}}$, men: $\chi^{2}(2)=1.51 ; \underline{\mathrm{ns}}$ ], social status [women: $\chi^{2}(3)=3.08$; $\underline{\mathrm{ns}}$, men: $\chi^{2}(3)=1.15 ; \underline{\mathrm{ns}}$ ], education [women: $\chi^{2}(3)=.88 ; \underline{\mathrm{ns}}$, men: $\chi^{2}(3)=1.79 ; \underline{\mathrm{ns}}$ ], premarital cohabitation [women: $\chi^{2}(1)=1.00 ; \underline{\mathrm{ns}}$, men: $\chi^{2}(1)=.30 ; \underline{\mathrm{ns}}$ ] and presence of children [women: $\chi^{2}(1)=1.50$; $\underline{\mathrm{ns}}$, men: $\chi^{2}(1)=3.88 ; \underline{\mathrm{ns}}$ ] (see Table 1).

\section{Here table 1}

\section{Questionnaires}

Individuals responding to newspaper advertisements were mailed a questionnaire assessing demographic variables (as listed in Table 1) and a questionnaire assessing (a) who had initiated divorce, (b) the perception of similarity between both partners, (c) the evaluation of one's own and partner's attractiveness, (d) the comparison between the attractiveness of 
both partners and (e) comparison between the former partner and possible alternative partners and between the former marriage and earlier close relationship as described below.

Who initiated divorce? Participants had three possibilities to answer this question: (a) it was my decision, (b) it was the decision of my partner or (c) it was a common decision. Pettit and Bloom (1984) reported that "previous studies (Asher and Bloom, 1983; Darsa, 1977; Hetherington, Cox and Cox, 1977) have suggested that self-report of initiator status appears to have acceptable validity, in that both spouses generally agree". Moreover, Buehler, Hogan, Robinson \& Levy (1986) noticed that divorced persons were able to identify whether the decision to divorce was initiated by themselves, by the partner or by both of them.

Perception of the similarity between both partners was assessed with a 5 items scale. Participants indicated if they estimated that they and their partner were similar or different with regard to (a) personality, character, (b) values, norms, attitudes, (c) sexual needs, (d) goals, expectations, needs and (e) opinion regarding allocation of marital roles.

Evaluation of one's own and partner's attractiveness: 6 items evaluated one's own and partner's (a) physical/sexual, (b) social and (c) intellectual attractiveness on a 5 point Likertscale $(1=$ very unattractive to $5=$ very attractive $)$.

Comparison between one's own and partners' attractiveness: 6 items compared the (a) physical/sexual, (b) intellectual, (c) social, (d) salarial, and (e) professional attractiveness of the respondents compared to their partner's attractiveness. Participants indicated if they estimated themselves to be more attractive than their partner, as attractive as their partner or more attractive than their partner.

\section{Comparison of the partner's attractiveness to alternatives and to earlier close}

relationships: Participants had to indicate, if their former partner was attractive or unattractive at the beginning of the close relationship in comparison to alternatives and to earlier relationships. 
Results

To examine any differences between initiators and noninitiators we computed Chisquare analyses and analyses of variance. As the initiators and the noninitiators didn't differ with regard to the demographical variables, we didn't control these variables in the following analyses.

\section{$\underline{\text { Similarity/Difference between the both former partners }}$}

How did divorced participants evaluate similarity/difference between themselves and their partner with regard to initiator status? As table 2 shows, most participants (men and women) described themselves to be quite similar to their former spouse. Women who initiated divorce were significantly more likely than women who didn't to note differences between themselves and their partner with regard to (a) personality, character, (b) norms, values and attitudes, (c) sexual needs and (d) needs, expectations and goals. Men who decided to divorce were significantly less likely than non-initiators to reveal the similarity with their former wife with regard to the personality and character and marginally less likely with regard to norms, values and attitudes (see table 2).

\section{$\underline{\text { One's own and partner's attractiveness }}$}

To evaluate the difference of perception of one's own and the partner's attractiveness for initiator and non-initiator, a 2 x 2 (initiative $\mathrm{x}$ attractiveness) multivariate analysis of variance was conducted for physical/sexual, social and intellectual attractiveness in women and men. For women, MANOVA revealed significant effects for both factors [initiative: $\underline{F}$ (3, $325)=3.93 ; \underline{\mathrm{p}}<.01 ;$ attractiveness: $\underline{\mathrm{F}}(3,325)=5.56 ; \underline{\mathrm{p}}<.001]$ and a significant initiative $\mathrm{x}$ attractiveness interaction effect, $\underline{\mathrm{F}}(3,325)=6.35 ; \underline{\mathrm{p}}<.001$. For men, MANOVA revealed only a significant attractiveness effect, $\underline{\mathrm{F}}(3,185)=24.75 ; \underline{\mathrm{p}}<.001$. These results are presented in Table 3. Simple effect tests revealed that non-initiating women scored 
significantly higher on two subscales, physical/sexual and intellectual attractiveness, suggesting that non-initiating women perceived more attractiveness in their former couple. Moreover, women perceived their partner to be physically/sexually and socially more attractive than themselves, but intellectually less attractive. Initiative $\mathrm{x}$ attractiveness interaction effects were apparent on the three subscales. Men (independently of initiator status) perceived their female partner to be physically/sexually more attractive than themselves, but socially and intellectually less attractive. Moreover, we were able to find an initiative $\mathrm{x}$ attractiveness interaction effect on the subscale assessing the intellectual attractiveness (see table 3).

\section{Comparison between one's own and partners' attractiveness}

As table 4 shows, a quarter of the initiating women described their former partner to be physically/sexually less attractive than themselves, whereas only a tenth of non-initiating women did so. Women who didn't make the decision to divorce were more numerous than women who did to perceive their spouse to be as attractive as they were. Twice as much initiating than non-initiating women evaluated their partner to be intellectually and socially less attractive than themselves. Moreover twice as much female non-initiator than subjects who initiated divorce described their partner to be intellectually more attractive than themselves. Initiating women were more numerous than non-initiating to state that their partner had a lower income and a lower degree of education than themselves. Furthermore, a greater number of non-initiating women affirmed that their partner had a higher degree of education than themselves. It is noteworthy that the percentage of women who admitted that their former partner had a higher income than themselves was quite similar in initiating and non-initiating women.

Men who decided to divorce were more numerous than men who did not to evaluate their former partner to be physically/sexually and intellectually less attractive than 
themselves. Moreover, compared to the non-initiating men, men who initiated divorce were more numerous to report a lower degree of education of their former spouse (see table 4).

\section{Comparison of the partner's attractiveness to alternatives and to previous close} relationships

At the beginning of the close relationship, $17.2 \%$ of women who later initiated divorce perceived their former partner to be unattractive compared to other alternatives. Only $6.5 \%$ of non-initiating women did so, $\chi^{2}(1)=6.23, \underline{p}<.05$. Among men, $9.5 \%$ of initiators and $6.5 \%$ of non-initiators considered their partner to be unattractive compared to other alternatives, $\chi^{2}$ $(1)=.61$, ns. Compared to previous relationship, $24.3 \%$ of the initiator women and $17.0 \%$ of non-initiating women reported that their former spouse was unattractive, $\chi^{2}(1)=1.92$, $\underline{\mathrm{ns}}$. $17.1 \%$ of men who decided to divorce and $15.9 \%$ of men who were left considered that their wife was attractive at the beginning of the close relationship compared to previous relationships, $\chi^{2}(1)=.05$, $\underline{\mathrm{ns}}$.

\section{Discussion}

The current study compared the similarity and attractiveness of the partner who decided to divorce with the spouse who did not. We focused on initiator status and sex differences. With regard to subjective similarity and differences between both spouses at the beginning of the close relationship, it is noteworthy that, independently of initiator status, most of the participants perceived themselves and their former partner to be rather similar. It would be captivating in further studies to observe, if recently divorced people would perceive more differences between themselves and their former partner than divorcees with a longer delay since divorce and who had more time to "assimilate" to divorce and to be perhaps less concerned by a "resentment bias" and desire to be different, or if, in opposite, the recently 
divorced individuals perceived more similarity, because they had less time to "redefine their identity as distinct from the identity of both the former couple and the former spouse" (DuranAydintug, 1995; Vaughan, 1986).

As far as women are concerned, initiating were more numerous than non-initiating women to report differences between themselves and their ex-spouse with regard to (a) personality, character traits, (b) norms, values, attitudes, (c) sexual needs and (d) expectations, general needs, and goals. Our cross-sectional data didn't unfortunately permit us to consider if the perceived lack of similarity caused marital distress and triggered the decision to divorce or, in opposite, if the distressed spouses more focused on differences between themselves and their partner.

Male initiators and non-initiators only distinguished with regard to similarity/differences in personality, character. We were not able to observe another significant distinction between initiators and non-initiators.

How can we explain the fact that female initiators were significantly more frequent than non-initiating to report differences between themselves and their former partners in different areas and that initiating and non-initiating men only distinguished with regard to personality and marginally with regard to norms, values and attitudes? Based on equity theory, we guess that women are more responsive to unfairness, are more oriented toward intimate features of marital relationship (Thompson \& Walker, 1989), thus they may be more inclined to focus on perceived differences and to be frustrated by them. Moreover, studies based on the initiator status theory reported that the partner who decided to leave can feel responsible for the end of the marriage and can develop feelings of guilty and remorse (Weiss, 1975). To focus on the differences between themselves and the partner can be a strategy to cope with this difficult critical life event by convincing oneself that the decision was adequate. We hypothesize that women are more tending to ruminate on the events, to feel 
more negative emotions such as culpability, remorse, etc. (Strauss, Muday, McNall \& Wong, 1997) and that they try to cope with them by focusing more often than men on differences with the former spouse. Moreover, results can be biased in the fact that the most divorces were initiated by women, but could be motivated by men (infidelity, alcohol problem, violence, etc.). Both categories "initiator men" and "non-initiator men" could be confused because the second group comprised men who in fact indirectly initiated divorce.

Another interesting result is that initiators and non-initiators (men and women) did not differ from each other with regard to the allocation of marital repartition. We can state that at the beginning of the close relationship, and especially at the moment of creating a family, men and women openly expressed their opinion with respect to the sharing of the tasks.

In one hand, differences between women who initiated divorce and women who didn't weren't so relevant as far as their own attractiveness was concerned. On the other hand, it's really interesting to note that women who initiated divorce perceived their partner as less physically/sexually, socially and intellectually attractive than noninitiating women perceived their partner. It seems that women didn't take into account their own attractiveness in their decision to divorce, but rather the attractiveness of their partner. Maybe initiator women developed a negative view of their former partner, and noninitiating women felt as victims.

Men, independently of their initiator status, considered themselves to be physically/sexually less attractive than their former spouse, but to be socially and intellectually more attractive. This fact corresponds with the theory saying that men offer social status and women physical beauty (e.g. Berry \& Miller, 2001; Buss, 1989; Howard et al., 1987).

Asking women to compare themselves with their former partner, more numerous initiating women than noninitiating evaluated their ex-spouse to be less physically/sexually, intellectually, socially, professionally and economically attractive than themselves. More 
initiating men than noninitiating perceived their partner to be less physically/sexually, intellectually and professionally attractive. With regard to equity theory (Walster et al., 1978), we can assume that initiators were more under benefited in their relationship than their partners and with regard to the theory of Levinger (1976), we can imagine that initiators will have more alternatives in the future.

There are some limitations in this study. First, we used a retrospectively selfevaluation with all biases that this methodology comprises. Second, we only took into account the retrospectively perceived attractiveness at the beginning of the relationship. This perception can be biased after divorce. Third, we did not assess self-esteem, a potentially important mediator variable. Indeed, people who took the initiative to divorce could have more control over the divorce process (Duran-Aydintug, 1995; Thuen, 2000) and could develop a better self-esteem. Non-initiators could feel as the rejected one (Vannoy, 1995; Wallerstein \& Kelly, 1980; Weiss, 1975) and could have more difficulties to cope with divorce (Duran-Aydintug, 1995; Spanier \& Casto, 1979; Vaughan, 1986; Weiss, 1975). Assuming that initiators have a better self-esteem, it is also likely that they perceive themselves to be more attractive than their partner. Fourth, we didn't take account people who declared that divorce was a mutual decision. It's also possible that we biased the differences between women and men. Indeed, $13 \%$ of the women estimated that the decision was a mutual one and $24 \%$ of men perceived the decision as a mutual one.

In further studies, it would be interesting to examine the links between the reasons to divorce, the barriers and the alternatives and the perceived similarity between the both spouses and the subjective attractiveness. Indeed, we can imagine that women who decided to divorce because their partner reported alcohol or drugs problems or violence did not take into account their own physical/sexual attractiveness or the alternatives. For her, living as a single is a better alternative than the current relationship even though no new partner is available. 
What could be the usefulness and the relevance of this study for people working with couples and therapists? First, this study pointed out the fact that people estimated to be quite similar to their former partner at the beginning of their relationship. This result refuted the stereotype that people who divorced were partners who were "bad assorted" and that divorce was a logical end to this love story. Second, as some researchers already demonstrated (Pasley, Kerpelman \& Guilbert, 2001), the similarity between partners often was high at the beginning of the relationship and decreased with the years. It's known that this similarity facilitated the comprehension and the communication between the partners and diminished the probability of conflicts (Bodenmann, 2001; Kurdek, 1993). It would also be profitable to couples to participate at this moment in a prevention program (e.g. the Couples Coping Enhancement Training of Bodenmann, 2004) and to maximise their communication, coping and problem solving skills. Moreover, in such training, the importance of equity and fairness in the couple was discussed. Third, it's possible for therapists, at the beginning of the therapy, to focus on the previous similarity between the partners and in this way to activate some positive resources (cf. Oral History, Buehlman \& Gottman, 1996). 


\section{References}

Amato, P.R., Previti, D. (2003). People's reasons for divorcing: gender, social class, the life course, and adjustment. Journal of Family Issues, 24, 602-626.

Archer, J. (1996). Sex differences in social behaviour: are the social role theory and evolutionary explanations compatible? American Psychologist, 51, 909-917.

Asher, S.J., \& Bloom, B.L. (1983). Geographic mobility as a factor in adjustment to divorce. Journal of Divorce, $\underline{6}, 69-84$.

Becker, G.S. (1981). A treatise on the family. Cambridge, MA: Harvard University Press.

Berry, D.S., \& Miller, K.M. (2001). When boy meets girl: attractiveness and the fivefactor model in opposite-sex interactions. Journal of Research in Personality, 35, 62-77.

Berscheid, E., \& Walster, E. (1974). Psychological attractiveness. In Berklowitz, L. (ed.), Advances in Experimental Social Psychology, Academic Press, New York.

Black, L.E., Eastwood, M.M., Sprenkle, D.H., \& Smith, E. (1991). An exploratory analysis of the construct of leavers versus left as it relates to Levinger's social exchange theory of attractions, barriers, and alternative attractions. Journal of Divorce and Remarriage, $15,127-139$.

Bodenmann, G. (2001). Psychologische Risikofaktoren für Scheidung: ein Überblick. Psychologische Rundschau, 52, 85-95.

Bodenmann, G., \& Shantinath, S. D. (2004). The Couples Coping Enhancement Training (CCET): a new approach to prevention of marital distress based upon stress and coping. Family Relations, 53, 477-484

Booth, A., Johnson, D.R., White, K.L., \& Edwards, J.N. (1986). Divorce and marital instability over the life course. Journal of Family Issues, 7, 421-442. 
Bradbury, T.N., Fincham, F.D., \& Beach, S. (2000). Research on the nature and determinants of marital satisfaction: a decade in review. Journal of Marriage and the Family, $\underline{62}, 964-980$.

Bramlett, M.D., \& Masher, W.D. (2002). Cohabitation, marriage, divorce and remarriage in the United States. Vital Health Statistics, 23, 1-93.

Braver, S.L., Whitley, M., \& Ng, C. (1993). Who divorce whom? Methodological and theoretical issues. Journal of Divorce \& Remarriage, 20, 1-19.

Buehler, C., Hogan, M., Robinson, B., \& Levy, R. (1986). The parental divorce transition: divorce-related stressors and well-being. Journal of Divorce, $\underline{9}$, 61-81.

Buehlman, K., \& Gottman, J.M. (1996). The oral history interview and the oral history coding system. Mahwah, NJ: Erlbaum.

Buunk, B.P., \& Mutsaers, W. (1999). Equity perceptions and marital satisfaction in former and current marriage: a study among the remarried. Journal of Social and Personal Relationships, 16, 123-132.

Buunk, B.P., \& VanYperen, N.W. (1991). Referential comparison, equality, and relationship satisfaction: gender differences over a ten-year period. Social Justice Research, 3, 157-180.

Buss, D.M. (1984). Marital assortment for personality dispositions: assessment with three different data sources. Behavior Genetics, 14, 111-123.

Buss, D.M. (1989). Sex differences in human selection: evolutionary hypotheses tested in 37 cultures. Behavioral and Brain Sciences, 12, 1-49.

Buss, D., \& Barnes, M. (1986). Preferences in human mate selection. Journal of Personality and Social Psychology, 50, 559-570.

Cate, R.M., Lloyd, S.A., Henton, J.M., \& Larson, J.H. (1982). Fairness and reward level as predictors of relationship satisfaction. Social Psychology Quarterly, 45, 177-181. 
Chang, J. (2000). Self-reported reasons for divorce and correlates of psychological well-being among divorced Korean immigrant women. Journal of Divorce \& Remarriage, $\underline{40}$, 111-128.

Darsa, S.D. (1977). Initiation to divorce as a function of locus of control, selfactualization, and androgyny. Dissertation Abstracts International, 37, 4671B.

Deutsch, M. (1975). Equity, equality and need: what determines which value will be used as the basis of distributive justice? Journal of Social Issues, $\underline{31}$, 137-150.

Duran-Aydintug, C. (1995). Former spouse interaction: normative guidelines and actual behavior. Journal of Divorce and Marriage, 22, 147-161.

Eagly, A. (1987). Sex differences in social behaviour: A social role interpretation. Hillsdale, NJ: Erlbaum.

Eurostat (2001). Annuaire Eurostat 2001. de A comme agriculture à Z comme zone euro. L'Europe des années 1990 vue à travers les chiffres. Office statistique des Communautés européennes, No 64, Luxembourg.

Feingold, A. (1988). Matching for attractiveness in romantic partners and same-sex friends: a meta-analysis and theoretical critique. Psychological Bulletin, 104, 226-235.

Feng, D., \& Baker, L. (1994). Spouse similarity in attitudes, personality, and psychological well-being. Behavior Genetics, 24, 357-364.

Gilger, J.W. (1991). Differential assortative mating found for academic and demographic variables as function of time and assessment. Behavioral Genetics, 2 , 131-149.

Glenn, N.D. (1990). Quantitative research on marital quality in the 1980s: a critical review. Journal of Marriage and the Family, $\underline{52}$, 818-831.

Glenn, N.D. (1991). Quantitative research on marital quality in the 1980s: a critical review. In A. Booth (Ed.), Contemporary families: Looking forward, looking back (pp. 2841). Minneapolis, MN: National Council on Family Relations. 
Goodman, C.C. (1993). Divorce after long term marriages: formers spouse relationships. Journal of Divorce \& Remarriage, 20, 43-61.

Hatfield, E., Utne, M.K., \& Traupman, J. (1979). Equity theory and intimate relationships. In R.L. Burgess and T.L. Huston (eds.), Social Exchange in Developing Relationships (pp. 99-133). New York: Academic Press.

Heaton, T.B., \& Albrecht, S.L. (1991). Stable unhappy marriages. Journal of Marriage and the Family, $\underline{53}$, 747-758.

Hetherington, E.M., Cox, M., \& Cox, R. (1977). The aftermath of divorce. In J.E. Stevens \& M. Matthews (Eds.), Mother-Child, Father-Child Relations (pp. 149-176). Washington DC: National Association for the Education of Young Children.

Hopper, J. (1993). The rhetoric of motives in divorce: a scale and its application. Journal of Marriage and the Family, 55, 801-813.

Howard, J.A., Blumstein, P., \& Schwartz, P. (1987). Social or evolutionary theories? Some observations on preferences in human mate selection. Journal of Personality and Social Psychology, 53, 194-200.

Johnson, D.R., Amoloza, T.O., \& Booth, A. (1992). Stability and developmental change in marital quality: a three-wave panel analysis. Journal of Marriage and the Family, $\underline{54}, 582-594$.

Johnson, M.P., Caughlin, J.P., \& Huston, T.L. (1999). The tripartite nature of marital commitment: personal, moral, and structural reasons to stay married. Journal of Marriage and the Family, $\underline{61}, 160-177$.

Kenrick, D.T. \& Trost, M.R. (1993). The evolutionary perspective. In A.E. Beall, \& R.J. Sternberg (Eds.), The psychology of gender. New York: Guilford Press.

Klein, R. (1991). Modelle der Partnerwahl. In Amelang, M., Ahrens, H.-J. \& Bierhoff, H.W. (Eds.). Partnerwahl und Partnerschaft. Göttingen: Hogrefe. 
Knoester, C., \& Booth, A. (2000). Barriers to divorce. When are they effective? When are they not? Journal of Family Issues, 21, 78-99.

Kurdek, L.A. (1993). Predicting marital dissolution: a 5-year prospective longitudinal study of newlywed couples. Journal of Personality and Social Psychology, $\underline{64}, 221-242$.

Levinger, G. (1976). A social psychological perspective on marital dissolution. Journal of Social Issues, $\underline{32}, 21-42$.

Levinger, G. (1979). A social psychological perspective on marital dissolution. In G. Levinger and O.C. Moles (Eds.), Divorce and Separation (pp. 37-60). New York: Basic Books.

Lewak, R.W., Wakefield, J.A.Jr., \& Briggs, P.F. (1985). Intelligence and personality in mate choice and marital satisfaction. Personality and Individual Differences, $\underline{6}, 471-477$.

Lewis, R.A. \& Spanier, G.B. (1979). Theorizing about the quality and stability of marriage. In W.R. Burr, R. Hill, F.I. Nye and I.L. Reiss (Eds.), Contemporary theories about the family (Vol. 1, pp. 268-294). New York: Free Press.

Lykken, D.T., \& Tellegen, A. (1993). Is human mating adventitious or the result of lawful choice? A twin study of mate selection. Journal of Personality and Social Psychology, $\underline{65}, 56-68$.

Meyers, M.F. (1995). Men and divorce. NY: The Guilford Press.

Nagoshi, C.T., \& Johnson, R.C. (1994). Phenotypic assortment versus social homogamy for personality, education, attitudes and language use. Personality and Individual Differences, $\underline{17}, 755-761$.

Pasley, K., Kerpelman, J., \& Guilbert, D.E. (2001). Gendered conflict, identity disruption, and marital instability: expanding Gottman's model. Journal of Social and Personal Relationships, $\underline{18}$, 5-27. 
Pettit, E., \& Bloom, B. (1984). Whose decision was it? The effects of initiator status on adjustment to marital disruption. Journal of Marriage and the Family, 46, 567-595.

Prins, K.S., Buunk, B.P., \& VanYperen, N.W. (1993). Equity, normative disapproval and extramarital relationships. Journal of Social and Personal Relationships, $\underline{10}, 39-53$.

Richard, L.S., Wakefield, J.A.Jr., \& Lewak, R. (1990). Similarity of personality variables as predictors of marital satisfaction: A Minnesota Multiphasic Personality Inventory (MMPI) item analysis. Personality and Individual Differences, $\underline{11}$, 39-43.

Rokach, R., Cohen, O., \& Dreman, S. (2004). Who pulls the triggers? Who initiates divorce among over 45-year-olds. Journal of Divorce \& Remarriage, $\underline{42}$, 61-83.

Rusbult, C. E. (1983). A longitudinal test of the investment model: The development (and deterioration) of satisfaction and commitment in heterosexual involvments. Journal of Personality and Social Psychology, $\underline{45}, 101-117$.

Russel, R.J.H., \& Wells, P.A. (1991). Personality similarity and quality of marriage. Personality and Individual Differences, $12,407-412$.

Russel, R.J.H., \& Wells, P.A. (1994). Predictors of happiness in married couples. Personality and Individual Differences, $17,313-321$.

Sayers, S.L., Kohn, C.S., \& Heavey, C. (1998). Prevention of marital dysfunction: Behavioural approaches and beyond. Clinical Psychology Review, 18, 713-744.

South, S.J., \& Lloyd, K.M. (1995). Spousal alternatives and marital dissolution. American Sociological Review, 60, 21-35.

Spanier, G., \& Casto, R. (1979). Adjustment to separation and divorce: A qualitative analysis: In G. Levinger \& O. Males (Eds.), Divorce and separation: Context causes consequences (pp. 211-227). New York: Basic Books.

Sprecher, S. (1986). The relationship between inequity and emotions in close relationships. Social Psychology Quarterly, $\underline{49}$, 309-321. 
Stevenson, J., \& Fielding, J. (1985). Rating of temperament in families of young twins. British Journal of Developmental Psychology, $\underline{3}, 143-152$.

Strauss, J., Muday, T., McNall, K., \& Wong, M. (1997). Response style theory revisited: gender differences and stereotypes in rumination and distraction. $\underline{\text { Sex Roles}}, \underline{36}$, 771-792.

Sweeney, M.M. (2002). Remarriage and the nature of divorce. Does it matter which spouse chose to leave? Journal of Family Issues, $\underline{23}$, 410-440.

Thibaut, J.W., \& Kelley, H.H. (1959). The social psychology of groups. New York: John Wiley.

Thompson, L., \& Walker, A. (1989). Gender in families: women and men in marriage, work and parenthood. Journal of Marriage and the Family, 51, 845-871.

Thuen, F. (2000). Psychiatric symptoms and perceived need for psychiatric care after divorce. Journal of Divorce and Remarriage, $\underline{34}$, 61-76.

Townsend, J.M., \& Wasserman, T. (1997). The perception of sexual attractiveness: sex differences in variability. Archives of Sexual Behavior, 26, 243-268.

Trent, K., \& South, S.J. (2003). Spousal alternatives and marital relations. Journal of Family Issues, $24,787-810$.

Udry, J.R. (1981). Marital alternatives and marital disruption. Journal of Marriage and the Family, $\underline{43}$, 889-898.

Vannoy, D.A. (1995). A paradigm of roles in the divorce process: implications for divorce adjustment, future commitments and personal growth. Journal of Divorce and Remarriage, 24, 71-87.

Vaughan, D. (1986). Uncoupling: turning points in intimate relationships. New York: Oxford University Press. 
Wallerstein, J.S., \& Kelly, J.B. (1980). Surviving the breakup: how children and parents cope with divorce? New York: Basic Books.

Walster, E., Traupman, S., \& Walster, G.W. (1978). Equity and extramarital sex. The Archives of Sexual Behavior, 7, 127-142.

Walster, E., Walster, G.W., \& Berscheid, E. (1978). Equity: Theory and Research. Boston: Allyn and Bacon.

Weiss, R.S. (1975). Marital separation. New York: Basic Books.

White, L.K., \& Booth, A. (1991). Divorce over the life course: The role of marital happiness. Journal of Family Issues, 12, 5-21.

Zimmer, M. (2001). Explaining marital dissolution: the role of spouses' traits. Social Science Quarterly, 82, 464-477. 
Table 1: Sociodemographic characteristics of female and male initiators and noninitiators of the decision to divorce

\begin{tabular}{|c|c|c|c|c|c|c|c|c|}
\hline & \multicolumn{4}{|c|}{ Women } & \multicolumn{4}{|c|}{ Men } \\
\hline & \multicolumn{2}{|c|}{$\begin{array}{l}\text { Initiators } \\
(\mathrm{N}=265)\end{array}$} & \multicolumn{2}{|c|}{$\begin{array}{c}\text { Noninitiators } \\
(\mathrm{N}=101)\end{array}$} & \multicolumn{2}{|c|}{$\begin{array}{l}\text { Initiators } \\
(\mathrm{N}=90)\end{array}$} & \multicolumn{2}{|c|}{$\begin{array}{l}\text { Noninitiators } \\
(\mathrm{N}=124)\end{array}$} \\
\hline & $\mathrm{M}(\mathrm{SD})$ & Range & $\mathrm{M}(\mathrm{SD})$ & Range & $\mathrm{M}(\mathrm{SD})$ & Range & $\mathrm{M}(\mathrm{SD})$ & Range \\
\hline Age at marriage & $24.15(4.62)$ & $16-41$ & $24.46(4.24)$ & $17-40$ & $27.51(5.20)$ & $20-45$ & $28.93(5.53)$ & $18-49$ \\
\hline Years married & $13.52(8.17)$ & $0.50-38.50$ & $14.99(9.03)$ & $1.00-36.00$ & $12.44(7.22)$ & $0.50-30.00$ & $12.91(7.48)$ & $1.50-34.00$ \\
\hline Years separated & $5.55(6.12)$ & $0.50-29.00$ & $4.36(5.02)$ & $0.50-21.00$ & $4.33(4.68)$ & $0.50-22.00$ & $4.65(5.08)$ & $0.50-22.00$ \\
\hline Children & \multicolumn{2}{|c|}{$87.2 \%$} & \multicolumn{2}{|c|}{$82.2 \%$} & \multicolumn{2}{|c|}{$82.0 \%$} & \multicolumn{2}{|c|}{$91.1 \%$} \\
\hline \multicolumn{9}{|l|}{ Land } \\
\hline Germany & \multicolumn{2}{|c|}{$55.5 \%$} & \multicolumn{2}{|c|}{$54.5 \%$} & \multicolumn{2}{|c|}{$22.2 \%$} & \multicolumn{2}{|c|}{$18.5 \%$} \\
\hline Italy & \multicolumn{2}{|c|}{$20.0 \%$} & \multicolumn{2}{|c|}{$24.8 \%$} & \multicolumn{2}{|c|}{$21.1 \%$} & \multicolumn{2}{|c|}{$21.8 \%$} \\
\hline Switzerland & \multicolumn{2}{|c|}{$24.5 \%$} & \multicolumn{2}{|c|}{$20.8 \%$} & \multicolumn{2}{|c|}{$56.7 \%$} & \multicolumn{2}{|c|}{$59.7 \%$} \\
\hline \multicolumn{9}{|l|}{ Religion } \\
\hline Education & & & & & & & & \\
\hline Grade school & 20.0 & & & $\%$ & & $6 \%$ & & $8 \%$ \\
\hline High school & 32.7 & & & $\%$ & & $1 \%$ & & $1 \%$ \\
\hline College & 24.2 & & & $\%$ & & $6 \%$ & & $8 \%$ \\
\hline University & 23.1 & & & $\%$ & & $8 \%$ & & $3 \%$ \\
\hline Social status & & & & & & & & \\
\hline Low & 19.5 & & & $\%$ & & $8 \%$ & & $1 \%$ \\
\hline Medium & 65.9 & & & $\%$ & & $9 \%$ & & \\
\hline High & 14.6 & & & $\%$ & & $2 \%$ & & \\
\hline
\end{tabular}


Table 2: Similarity and difference between the former spouses for initiator and noninitiator participants

\section{Women}

\begin{tabular}{|c|c|c|c|c|c|}
\hline & \multicolumn{2}{|c|}{ Own initiative } & \multicolumn{2}{|c|}{ Partner's initiative } & \multirow[b]{2}{*}{ Chi2 } \\
\hline & Similar & Different & Similar & Different & \\
\hline Personality, character & $47.7 \%$ & $52.3 \%$ & $60.9 \%$ & $39.1 \%$ & $4.61^{*}$ \\
\hline Norms, values, attitudes & $68.8 \%$ & $31.3 \%$ & $84.4 \%$ & $15.6 \%$ & $8.19 * *$ \\
\hline Sexual needs & $59.8 \%$ & $40.2 \%$ & $80.4 \%$ & $19.6 \%$ & $12.49 * * *$ \\
\hline Needs, expectations, goals & $70.9 \%$ & $29.1 \%$ & $84.6 \%$ & $15.4 \%$ & $6.56 * *$ \\
\hline \multirow{4}{*}{$\begin{array}{l}\text { Opinion regarding allocation } \\
\text { of marital roles }\end{array}$} & $79.5 \%$ & $20.5 \%$ & $84.8 \%$ & $15.2 \%$ & 1.20 \\
\hline & \multicolumn{5}{|c|}{ Men } \\
\hline & \multicolumn{2}{|c|}{ Own initiative } & \multicolumn{2}{|c|}{ Partner's initiative } & \\
\hline & Similar & Different & Similar & Different & Chi2 \\
\hline Personality, character & $52.4 \%$ & $47.6 \%$ & $66.7 \%$ & $33.3 \%$ & 4.03* \\
\hline Norms, values, attitudes & $71.1 \%$ & $28.9 \%$ & $81.5 \%$ & $18.5 \%$ & $2.86^{+}$ \\
\hline Sexual needs & $59.5 \%$ & $40.5 \%$ & $66.7 \%$ & $33.3 \%$ & 1.04 \\
\hline Needs, expectations, goals & $79.8 \%$ & $20.2 \%$ & $72.9 \%$ & $27.1 \%$ & 1.21 \\
\hline $\begin{array}{l}\text { Opinion regarding allocation } \\
\text { of marital roles }\end{array}$ & $77.4 \%$ & $22.6 \%$ & $84.3 \%$ & $15.7 \%$ & 1.47 \\
\hline
\end{tabular}

Note:

$* * *: \mathrm{p}<.001 ; * *: \mathrm{p}<.01 ; *: \mathrm{p}<.05 ;^{+}: \underline{\mathrm{p}}<.1$ 
Table 3: Own and partner's attractiveness for initiator and noninitiator participants

\section{Women}

Results for Simple Effects Tests

\begin{tabular}{lccccccc}
\hline & \multicolumn{2}{c}{ Own initiative } & \multicolumn{2}{c}{ Partner's initiative } & F & F & F \\
& $\begin{array}{c}\text { Own } \\
\text { attracti- } \\
\text { veness }\end{array}$ & $\begin{array}{c}\text { Partner's } \\
\text { attracti- } \\
\text { veness }\end{array}$ & $\begin{array}{c}\text { Own } \\
\text { attracti- } \\
\text { veness }\end{array}$ & $\begin{array}{c}\text { Partner's } \\
\text { attracti- } \\
\text { veness }\end{array}$ & $\begin{array}{l}\text { Initiative } \\
\text { Attracti- } \\
\text { veness }\end{array}$ & I*A \\
\hline Sexual & 3.44 & 3.34 & 3.40 & 3.78 & $\mathbf{4 . 0 2}$ & $\mathbf{3 . 2 4}$ & $\mathbf{9 . 6 5}$ \\
attractiveness & $(1.05)$ & $(1.04)$ & $(1.01)$ & $(.95)$ & $*$ & + & $* *$ \\
Social & 3.23 & 3.12 & 3.15 & 3.55 & 2.57 & $\mathbf{3 . 4 5}$ & $\mathbf{1 1 . 0 6}$ \\
attractiveness & $(1.08)$ & $(1.10)$ & $(1.16)$ & $(1.12)$ & & + & $* * *$ \\
Intellectual & 3.64 & 3.27 & 3.75 & 3.77 & $\mathbf{1 1 . 4 0}$ & $\mathbf{5 . 3 3}$ & $\mathbf{6 . 7 3}$ \\
attractiveness & $(.88)$ & $(1.03)$ & $(1.00)$ & $(.93)$ & $* * *$ & $*$ & $* *$
\end{tabular}

\section{Men}

Results for Simple Effects Tests

\begin{tabular}{lccccccc}
\hline & \multicolumn{2}{c}{ Own initiative } & \multicolumn{2}{c}{ Partner's initiative } & F & F & F \\
& $\begin{array}{c}\text { Own } \\
\text { attracti- } \\
\text { ness }\end{array}$ & $\begin{array}{c}\text { Partner's } \\
\text { attracti- } \\
\text { veness }\end{array}$ & $\begin{array}{c}\text { Own } \\
\text { attracti- } \\
\text { veness }\end{array}$ & $\begin{array}{c}\text { Partner's } \\
\text { attracti- } \\
\text { veness }\end{array}$ & $\begin{array}{l}\text { Initiative } \\
\text { Attracti- } \\
\text { veness }\end{array}$ & I*A \\
\hline Sexual & 3.47 & 3.75 & 3.41 & 3.75 & .09 & $\mathbf{1 6 . 2 0}$ & .17 \\
attractiveness & $(.86)$ & $(.88)$ & $(.98)$ & $(.86)$ & & $* * *$ & \\
Social & 3.59 & 3.01 & 3.36 & 3.03 & .88 & $\mathbf{2 6 . 0 6}$ & 1.94 \\
attractiveness & $(.88)$ & $(1.03)$ & $(.95)$ & $(1.08)$ & & $* * *$ & \\
Intellectual & 3.96 & 3.27 & 3.76 & 3.40 & .12 & $\mathbf{3 7 . 7 9}$ & $\mathbf{3 . 6 4}$ \\
attractiveness & $(.72)$ & $(.99)$ & $(.87)$ & $(1.02)$ & & $* * *$ & + \\
\hline
\end{tabular}

Note:

$* * *: \underline{p}<.001 ; * *: \underline{p}<.01 ; *: \underline{p}<.05 ;^{+}: \underline{p}<.1$

Simple effects for Initiative and for Attractiveness were determined via ANOVAs 
Table 4: Comparison between the own and partners' attractiveness with respect to the initiator status

\section{Women}

\begin{tabular}{|c|c|c|c|c|c|c|c|}
\hline & \multicolumn{3}{|c|}{ Own initiative } & \multicolumn{3}{|c|}{ Partner's initiative } & \multirow[b]{2}{*}{ Chi2 } \\
\hline & $\begin{array}{c}\text { Partner } \\
\text { less } \\
\text { attractive }\end{array}$ & $\begin{array}{c}\text { Partner } \\
\text { as } \\
\text { attractive }\end{array}$ & $\begin{array}{c}\text { Partner } \\
\text { more } \\
\text { attractive }\end{array}$ & $\begin{array}{c}\text { Partner } \\
\text { less } \\
\text { attractive }\end{array}$ & $\begin{array}{c}\text { Partner } \\
\text { as } \\
\text { attractive }\end{array}$ & $\begin{array}{c}\text { Partner } \\
\text { more } \\
\text { attractive }\end{array}$ & \\
\hline $\begin{array}{l}\text { Sexual } \\
\text { Attractiveness }\end{array}$ & $27.1 \%$ & $51.3 \%$ & $21.7 \%$ & $12.90 \%$ & $60.9 \%$ & $27.2 \%$ & $8.66 *$ \\
\hline $\begin{array}{l}\text { Intellectual } \\
\text { Attractiveness }\end{array}$ & $37.8 \%$ & $46.2 \%$ & $16.0 \%$ & $18.7 \%$ & $50.5 \%$ & $30.8 \%$ & $14.86 * * *$ \\
\hline $\begin{array}{l}\text { Social } \\
\text { Attractiveness }\end{array}$ & $28.3 \%$ & $38.4 \%$ & $33.3 \%$ & $12.1 \%$ & $47.3 \%$ & $40.7 \%$ & $9.50 * *$ \\
\hline Education & $34.7 \%$ & $46.9 \%$ & $18.4 \%$ & $19.8 \%$ & $44.0 \%$ & $36.3 \%$ & $13.94 * * *$ \\
\hline \multirow[t]{4}{*}{ Income } & $20.5 \%$ & $19.2 \%$ & $60.3 \%$ & $13.2 \%$ & $26.4 \%$ & $60.4 \%$ & 3.48 \\
\hline & \multicolumn{7}{|c|}{ Men } \\
\hline & \multicolumn{3}{|c|}{ Own initiative } & \multicolumn{3}{|c|}{ Partner's initiative } & \\
\hline & $\begin{array}{c}\text { Partner } \\
\text { less } \\
\text { attractive } \\
\end{array}$ & $\begin{array}{c}\text { Partner } \\
\text { as } \\
\text { attractive }\end{array}$ & $\begin{array}{c}\text { Partner } \\
\text { more } \\
\text { attractive }\end{array}$ & $\begin{array}{c}\text { Partner } \\
\text { less } \\
\text { attractive }\end{array}$ & $\begin{array}{c}\text { Partner } \\
\text { as } \\
\text { attractive }\end{array}$ & $\begin{array}{c}\text { Partner } \\
\text { more } \\
\text { attractive }\end{array}$ & Chi2 \\
\hline $\begin{array}{l}\text { Sexual } \\
\text { Attractiveness }\end{array}$ & $20.2 \%$ & $46.4 \%$ & $33.3 \%$ & $8.5 \%$ & $57.5 \%$ & $34.0 \%$ & $\mathbf{5 . 8 3}^{+}$ \\
\hline $\begin{array}{l}\text { Intellectual } \\
\text { Attractiveness }\end{array}$ & $49.4 \%$ & $38.6 \%$ & $12.0 \%$ & $32.4 \%$ & $54.6 \%$ & $13.0 \%$ & $5.98 *$ \\
\hline $\begin{array}{l}\text { Social } \\
\text { Attractiveness }\end{array}$ & $47.6 \%$ & $34.5 \%$ & $17.9 \%$ & $40.7 \%$ & $45.4 \%$ & $13.9 \%$ & 2.36 \\
\hline Education & $60.2 \%$ & $28.9 \%$ & $10.8 \%$ & $41.7 \%$ & $47.2 \%$ & $11.1 \%$ & $7.26 *$ \\
\hline Income & $62.7 \%$ & $20.5 \%$ & $16.9 \%$ & $67.3 \%$ & $23.4 \%$ & $9.3 \%$ & 2.29 \\
\hline
\end{tabular}

Note:

$* * *: \mathrm{p}<.001 ; * *: \mathrm{p}<.01 ;^{*}: \mathrm{p}<.05 ;^{+}: \mathrm{p}<.1$ 
Address correspondence to:

\section{Linda Charvoz}

Institute for Family Research and Counseling

University of Fribourg

Avenue de la gare 1

CH-1700 Fribourg, Switzerland

Phone number: +41263007357

Fax number: +412630096 85*

E-mail address: linda.charvoz@unifr.ch 